\title{
PRESTASI BELAJAR BAHASA INDONESIA SISWA KELAS VIII DI MTS TARBIYAH ISLAMIYAH DI KABUPATEN REJANG LEBONG
}

\author{
ERNI ARYATI \\ Erniaryati20@yahoo.co.id
}

\begin{abstract}
Rumusan masalah dalam penelitian ini adalah. Bagaimanakah prestasi belajar siswa pada mata pelajaran bahasa Indonesia kelas VIII di MTs tarbiyah Kabupaten Rejang Lebong. Bagaimanakah prestasi belajar bahasa Indonesia siswa kelas VIII di MTs Tarbiyah Islamiyah Kabupaten Rejang Lebong ?, adapun tujuan dalam penelitian ini, yaitu: Untuk mengetahui bagaimanakah prestasi belajar kelas VIII di MTs Tarbiyah Islamiyah Kabupaten Rejang Lebong. Metodologi yang digunakan dalam penelitian ini yaitu metode deskriptif dan pendekatan yang digunakan dalam penelitian ini yaitu pendekatan kuantitatif sederhana. Dari hasil penelitian penulis juga dapat memberikan saran untuk Siswa hendaknya lebih di motifasi untuk lebih berperan aktif dalam proses balajar mengajar. Tempat penelitian ini dilaksanakan di sekolah MTs Tarbiyah Islamiyah Kabupaten Rejang lebong. Waktu penelitian direncanakan pada bulan Agustus- September Data penelitian ini berupa hasil tes prestasi bahasa Indonesia aspek morfologi dan sintaksis.Sumber penelitian ini adalah siswa kelas VIII MTs Tarbiyah Islamiyah Kabupaten Rejang Lebong Tahun 2015/2016 dengan jumlah siswa 40 orang. Teknik pengumupulan data dalam penelitian ini adalah tes. Instrumen dalam penelitian ini adalah lembar tes siswa. Teknik analisis data yang digunakan dalam penelitian ini adalah tekhnik analisis data deskriptif. Dari hasil penelitian penulis dapat menyimpulkan bahwa Prestasi Belajar Bahasa Indonesia siswa kelas VIII di MTs Tarbiyah Islamiyah Kabupaten Rejang Lebong" berada pada rentang 70-79, dengan tingkat rata-rata sebesar 76,5 dan termasuk dalam kategori baik. Dari hasil penelitian penulis juga dapat memberikan saran siswa hendaknya lebih di motivasi untuk lebih berperan aktif dalam proses belajar mengajar. Bagi guru tidak hanya menguasai menguasai aspek morfologis dan sintaksis saja tetapi ada unsur lainnya juga.
\end{abstract}

Kata kunci: Prestasi Belajar, Bahasa Indonesia, MTs, Rejang Lebong

\section{Pendahuluan}

Pada dasarnya belajar adalah proses perubahan di dalam diri manusia dari apa yang tidak diketahui berubah menjadi tahu. Belajar adalah suatu bentuk pertumbuhan dan perubahan di dalam diri sesorang yang dinyatakan dalam cara- cara bertingkah laku yang baru berkat pengalaman dan latihan (Aqib, 2010 : 42) Belajar bahasa pada hakikatnya adalah belajar berkomunikasi. Oleh karena itu, pembelajaran bahasa diarahkan untuk meningkatkan kemampuan belajar dalam berkomunikasi.

Bahasa Indonesia merupakan salah satu mata pelajaran yang diajarkan disekolah yang mewakili peran penting dalam mengembangkan kemampuan berfikir siswa. Pelajaran bahasa Indonesia perlu diberikan kepada semua peserta didik untuk membantu peserta didik selalu berfikir logis, kritis,dan kreatif. Pembelajaran bahasa Indonesia diarahkan untuk meningkatkan kemampuan siswa dalam berkomunikasi dengan baik dan benar, baik secara lisan 
maupun tulisan. Pembelajaran bahasa Indonesia disekolah meliputi aspek kebahasaan (keerampilan berbahsa dan bersastra)

Aspek pembelajaran bahasa Indonesia di sekolah meliputi aspek kebahasaan : keterampilan berbahasa dan bersastra.

Berdasarkan ketiga ranah pembelajaran bahasa indonesia tersebut dalam penelitian ini dikhususkan pada aspek kebahasaan. Aspek kebahasaan yang di kaji mencakup unsur morfologi dan sintaksis.

Menurut Kusmiarti ( 2010 : 21 ) Morfologi adalah bagian dari ilmu bahasa yang membicarakan seluk beluk bentuk kata, serta pengaruh perubahanperubahan bentuk kata terhadap golongan dan arti kata, atau dengan kata lain dapat dikatakan bahwa morfologi mempelajari seluk beluk bentuk kata serta fungsi perubahan - perubahan bentuk kata itu, baik fungsi gramatik maupun semantik. Berbeda dengan sintaksis yang mempelajari hubungan antara kata/frase/ klausa/kalimat/ wacana.

Unsur kebahasaan dalam pembelajaran bahasa Indonesia di sekolah MTs sangat penting dikuasai oleh siswa.

Hasil penelitian bahwa penguasaan dalam pembelajaran bahasa Indonesia siswa masih rendah hal ini di lihat dari hasil keseluruhan pada siswa yang masih rendah.

Hal kegiatan yang tidak sesuai dengan seharusnya, hal ini memudahkan masih terjadi perbedaan antara yang seharusnya dengan kenyataan yang seharusnya.

Berdasarkan beberapa permasalahan di atas maka peneliti tertarik untuk melakukan penelitian dengan judul "Prestasi Belajar Bahasa Indonesia siswa kelas VIII di MTs Tarbiyah Islamiyah Kabupaten Rejang Lebong". Adapun tujuan penelitian ini adalah untuk mengetahui bagaimanakah prestasi belajar kelas VIII di MTs Tarbiyah Islamiyah Kabupaten Rejang Lebong. Ruang lingkup penelitian ini dibatasi pada prestai belajar siswa kelas VIII MTs Tarbiyah Islamiyah Kabupaten Rejang Lebong. Ruang lingkup penelitian prestasi belajar siswa dibatasi pada aspek kebahasaan yang mencakup aspek morfologi dan sintaksi.

\section{METODE PENELITIAN}

Penelitian ini menggunakan metode deskriptif. Ratna (2009: 3 ) mengatakan metode deskriptif dilakukan dengan cara mendeskripsikan fakta- fakta yang kemudian di susul dengan analisis. Subana dan Sudrajad dalam Aliadi (2011 : 30 ) mengatakan bahwa metode penelitian deskriptif menuturkan dan menafsirkan data yang berkenaan dengan fakta, keadaan, variabel, dan fenomena yang terjadi saat penelitian berlangsung dan menyajikan apa adanya. Pendekatan dalam penelitian ini menggunakan pendekatan kuantitatif sederhana. Menurut Sugiyono (2015 : 14) metode penelitian kuantitatif dapat di artikan sebagai metode penelitian yang berlandaskan pada filsafat positivisme digunakan untuk meneliti pada populasi atau sampel tertentu, teknik penambilan sampel pada umumnya di ambil secara random, pengumpulan data pada umumnya menggunakan instrumen penelitian, analisis data bersifat kuantitatif/ statistik dengan tujuan untuk meneliti hipotesis yang telah ditetapkan. 
Tempat penelitian ini dilaksanakan di sekolah MTs Tarbiyah Islamiyah Kabupaten Rejang lebong. Waktu penelitian direncanakan pada bulan Agustus- September

Data penelitian ini berupa hasil tes prestasi bahasa Indonesia aspek morfologi dan sintaksis.

Sumber penelitian ini adalah siswa kelas VIII MTs Tarbiyah Islamiyah Kabupaten Rejang Lebong Tahun 2015/2016 dengan jumlah siswa 40 orang.

Teknik pengumpulan data yang digunakan adalah :

Tabel Kisi- Kisi Prestasi belajar bahasa Indonesia

\begin{tabular}{|c|c|c|c|}
\hline No & $\begin{array}{l}\text { Aspek Pembelajaran Bahasa } \\
\text { Indonesia }\end{array}$ & Unsur & Alat \\
\hline 1 & Morfologi & $\begin{array}{l}\text { - Kata } \\
\text { - } \text { Morfem }\end{array}$ & $\begin{array}{l}5,16,19,20,23,24 \\
6,7,8,9,10, \\
11,12,13\end{array}$ \\
\hline 2 & Sintaksis & $\begin{array}{ll}\text { - } & \text { Wacana } \\
\text { - } & \text { Kalimat } \\
\text { - } & \text { Klausa } \\
\text { - } & \text { Frasa }\end{array}$ & $\begin{array}{l}3, \\
4,17,18,21,22 \\
1 \\
2\end{array}$ \\
\hline
\end{tabular}

Teknik analisis data yang digunakan dalam penelitian ini adalah tekhnik analisis data deskriptif, yaitu mendeskripsikan data yang diperoleh dari sumber data melalui tes, dengan menggunakan rumus presentasi (Djamarah, 2005 :302)

Tabel Kualifikasi Pembelajaran Bahasa Indonesia

\begin{tabular}{|c|c|c|}
\hline No & Rentang Skor & Kategori \\
\hline 1 & $80-100$ & Sangat baik \\
\hline 2 & $70-79$ & Baik \\
\hline 3 & $56-59$ & Cukup \\
\hline 4 & $45-55$ & Kurang \\
\hline 5 & $1-44$ & Sangat Kurang \\
\hline
\end{tabular}


Keterampilan menulis merupakan salah satu jenis keterampilan berbahasa yang harus dikuasai siswa. Banyak ahli telah mengemukakan pengertian menulis. Menulis adalah sebuah proses berkomunikasi secara tidak langsung antara penulis dengan pembacanya( Abidin, 2012 : 181) Ketepatan pengungkapan gagasan harus didukung dengan ketepatan bahasa yang digunakan, kosakata dan gramatikal dan penggunaan ejaan. Tarigan (2008: 3) keterampilan menulis adalah salah satu keterampilan berbahasa yang produktif dan ekspresif yang dipergunakan untuk berkomunikasi secara tidak langsung dan tidak secara tatap muka dengan pihak lain.

\section{Fungsi Menulis}

Menulis memiliki banyak fungsi. Seperti yang diungkapkan oleh D'Angelo dalam Tarigan, (2008), pada prinsipnya fungsi utama dari tulisan adalah sebagai alat komunikasi yang tidak langsung. Menulis sangat penting bagi pendidikan karena para pelajar akan merasa mudah dan nyaman dalam berpikir secara kritis. Juga dapat memudahkan kita merasakan dan menikmati hubungan-hubungan, memperdalam daya tangkap atau persepsi, memecahkan masalah-masalah yang dihadapi, menyusun urutan bagi pengalaman. Tulisan membantu kita menjelaskan pikiran-pikiran kita. Tidak jarang, kita menemui apa yang sebenarnya kita pikirkan dan rasakan mengenai orang-orang, gagasangagasan, masalah-masalah, dan kejadiankejadian yang hanya dalam proses menulis yang aktual.

Tidak jauh berbeda dari pendapat D’Angelo, Sabarti Akhadiah (dalam Hasani, 2005:3) mengungkapkan fungsi menulis sebagai berikut: a) Penulis dapat mengenali kemampuan dan potensi dirinya. Dengan menulis, penulis dapat mengetahui sampai mana pengetahuannya tentang suatu topik. Untuk mengembangkan topik itu, penulis harus berpikir menggali pengetahuan dan pengalamannya.

b) Penulis dapat terlatih dalam mengembangkan berbagai gagasan. Dengan menulis, penulis terpaksa bernalar, menghubung-hubungkan, serta membanding-banding-kan fakta untuk mengembangkan berbagai gagasan.

c) Penulis dapat lebih banyak menyerap, mencari, serta menguasai informasi se-hubungan dengan topik yang ditulis. Kegiatan menulis dapat memperluas wawasan penulisan secara teoritis mengenai fakta-fakta yang berhubungan.

d) Penulis dapat terlatih dalam mengorganisasikan gagasan secara sistematis serta mengungkapkan secara tersurat. Dengan demikian, penulis dapat memperjelas permasalahan yang semula masih samar.

e) Penulis dapat meninjau serta menilai gagasannya sendiri secara objektif.

f) Dengan menulis sesuatu di atas kertas, penulis akan lebih mudah memecahkan permasalahan, yaitu dengan menganalisisnya secara tersurat dalam konteks yang lebih kongkret.

g) Dengan menulis, penulis terdorong untuk terus belajar secara aktif.

h) Penulis menjadi penemu sekaligus pemecah masalah, bukan sekedar menjadi penyadap informasi dari orang lain. 
i) Dengan kegiatan menulis terencana, penulis membiasakan berpikir serta ber-bahasa secara tertib dan teratur.

j) Dari pernyataan tersebut, dapat disimpulkan fungsi dari menulis adalah sebagai alat komunikasi tidak langsung yang dapat menggali kemampuan seseorang tentang suatu topik dengan cara berlatih mengorganisasikan gagasan secara sistematis dan terencana agar dapat berbahasa dengan tertib dan teratur. Selain itu, menulis juga dapat membantu seseorang memperdalam daya tangkap dan membantu memecahkan masalah.

2. Tujuan Menulis

Pada dasarnya tujuan menulis adalah sebagai alat komunikasi dalam bentuk tulisan. Setiap jenis tulisan tentunya memiliki tujuan. Tujuan-tujuan tersebut tentunya sangat beraneka ragam. Tarigan (2008: 24) membagi tujuan menulis dilihat dari penulisnya yang belum berpengalaman sebagai berikut:

1) Memberitahukan atau mengajar

2) Meyakinkan atau mendesak

3) Menghibur atau menyenangkan

4) Mengutarakan atau mengekspresikan perasaan dan emosi yang berapi-api.

Sedangkan Hugo Hartig (dalam Tarigan 2008:26), membagi tujuan menulis menjadi tujuh bagian sebagai berikut:

1) Assigment purpose (Tujuan

Tujuan penugasan ini sebenarnya tidak mempunyai tujuan sama sekali. Penulis menulis sesuatu karena ditugaskan, bukan atas kemauan sendiri.

2) Altruistic purpose (Tujuan Altruistik)

Tujuan altruistik adalah kunci keterbacaan sesuatu tulisan. Penulis bertujuan untuk menyenangkan para pembaca, menghindarkan kedukaan para pembaca, ingin mendorong para pembaca memahami, menghargai perasaan, dan penala-rannya. Ingin membuat hidup para pembaca lebih mudah dan lebih menyenangkan dengan karya seseorang.

3) Persuasive purpose (Tujuan Persuasif)

Tulisan yang bertujuan meyakinkan para pembaca akan kebenaran gagasan yang diutarakan oleh seorang penulis.

4) Informational purpose (Tujuan Informasional, Tujuan Penerangan)

Tujuan yang bertujuan memberi informasi atau keterangan/penerangan kepada para pembaca.

5) Self-expressive purpose (Tujuan Pernyataan Diri)

Tulisan yang bertujuan untuk memperkenalkan atau menyatakan diri seorang pengarang kepada pembaca

6) Creative purpose (Tujuan Kreatif) Tujuan ini erat berhubungan dengan tujuan pernyataan diri, tetapi "keinginan kreatif" disini melebihi pernyataan diri, dan melibatkan dirinya dengan keinginan mencapai norma artistik atau seni yang ideal, seni idaman. Tulisan yang bertujuan mencapai nilai-nilai artistik dan nilai kesenian.

7) Problem solving purpose (Tujuan Pemecahan Masalah)

Penulis ingin memecahkan masalah yang dihadapi dengan cara menjelaskan, menjernihkan, menjelajahi serta meneliti secara cermat pikiran-pikiran dan gagasangagasannya sendiri agar dapat 
dimengerti dan diterima oleh pembaca.

Dari pernyataan tersebut dapat disimpulkan bahwa menulis haruslah mempunyai tujuan yang nyata. Dimana para penulis harus bisa meyakinkan, memberitahukan, menghibur dan mengekspresikan emosi.

Manfaat menulis menurut Sabarti Akhadiah (dalam Kartimi 2006: 5) sebagai berikut:

1) Mengetahui potensi diri dengan dan kemampuan serta pengetahuan kita tentang topik yang dipilih. Dengan mengembangkan topik itu kita dipaksa berpikir, menggali pengetahuan, dan pengalaman yang tersimpan dalam diri.

2) Dengan mengembangkan berbagai gagasan kita terpaksa bernalar, menghubung-hubungkan, dan membandingkan fakta-fakta yang tidak pernah kita lakukan kalau kita tidak menulis.

3) Lebih banyak menyerap, mencari, serta menguasai informasi sehubungan dengan topik yang ditulis. Dengan demikian, kegiatan menulis dapat memperluas wawasan baik secara teoritis maupun mengenai fakta-fakta yang berhubungan

4) Menulis berarti mengorganisasi gagasan secara sistematik serta mengungkapkan secara tersurat. Dengan demikian, setiap permasalahan yang semula samarsamar dakan menjadi lebih jelas.

5) Melalui tulisan, kita dapat menjadi peninjau dan penilaian gagasan kita secara obyektif

6) Lebih mudah memecahkan masalah dengan menganalisisnya secara tersurat dalam konteks yang lebih konkrit.

7) Dengan menulis, kita menjadi aktif berpikir sehingga kita dapat menjadi penemu sekaligus pemecah masalah. Bukan hanya sekedar penerima informasi yang pasif.

8) Membiasakan kita berpikir dan berbahasa secara tertib.

Selain manfaat menulis di atas, Hernowo (2004: 51) mengungkapkan bahwa menulis dapat digunakan untuk menyibak atau mengungkapkan diri. Dengan menulis seseorang bukan hanya akan menyehatkan fisik dan mental tetapi juga dapat mengenali detail-detail dirinya.

Dari beberapa manfaat menulis yang dikemukakan, dapat disimpulkan bahwa menulis bermanfaat untuk mengetahui kemampuan diri dengan aktif berpikir dalam menuangkan ide dan gagasan kedalam sebuah tulisan, menambah wawasan dan informasi, menumbuhkan keberanian dan kreatifitas.

Ragam tulisan dapat didasarkan pada isi tulisan, isi tulisan mempengaruhi jenis informasi, pengorganisasian dan tata sajian tulisan. Berdasarkan ragam tersebut tata tulisan dibedakan menjadi empat : deskripsi, eksposisi, argumentasi, narasi (Syafi'ie,1990: 151).sedangkan menurut Keraf(1989: 6) ragam tulisan didasarkan pada tujuan umum, berdasarkan hal tersebut menulis dapat dibedakan menjadi lima: Deskripsi, eksposisi, argumentasi, narasi, persuasi.

1. Deskripsi (perian)

Kata deskripsi berasal dari bahasa latin describere yang berarti menggambarkan atau memerikan sesuatuhal. Dari segi 
istilah,deskrpsi adalah suatu bentuk karangan yanng melukiskan sesuatu sesuai dengan keadaan yang sebenarnya sehingga pembaca dapat mencitrai (melihat,mendengar,mencim dan merasakan)apa yang dilikiskan itu sesuai dengan citra penulisannya.

\section{Eksposisi (paparan)}

Eksposisi berasal dari kata exposition yang berarti membuka.dapat pula diartikan sebagai tulisan yang bertujuan untuk memberitahu ,mengupas,menguraikan, atau menerangkan sesuatu.

\section{Argumentasi(bahasan )}

Yang dimaksud dengan tulisan argumentasi adalah karangan yang terdiri atas paparan alasan dan penyintesisan pendapat untuk membangun suatu kesimpulan.Karangan ini ditulis dengan maksud untuk memberikan alasan, memperkuat atau menolak sesuatu pendapat, pendirian, gagasan.

\section{Narasi (kisahan)}

Narasi atau naratif adalah tulisan berbentuk karangan yang menyajikan serangkaian peristiwa atau kejadian menurut urutan terjadinya (kronologis) dengan maksud memberi makna kepada sebuah atau rentetan kejadian sehingga pembaca dapat memetik hikmah dari cerita itu.

\section{Persuasi}

Tulisan yang bermaksud mempengaruhi orang lain dalam persuasi selain logika perasaan juga memegang peranan penting.

diperhatikan dalam kegiatan tulis menulis

Adapun hal-hal yang harus diperhatikan dalam kegiatan menulis adalah sebagai berikut: a. Penentuan Pikiran Utama

Salah satu cirri utama tulisan adalah adanya kesatuan gagasan antarparagrafnya. Sebuah tulisan (karangan) akan menjadi jelas jika mempunyai kesatuan, yaitu semua detail yang berupa contoh, alas an maupun fakta yang digunakan harus tidak menyimpang dari pikiran utama.

Seperti dikemukan oleh(Ahmadi dalam Masnur, 2009: 125), pikiran utama adalah pengendali suatu karangan sehingga pikiran utama dimaksudkan isi karangan tidak akan menyimpang. Karangan tersebut ditulis dalam bentuk paragraph dan tiap paragraph mempunyai pikiran utama. Pikiran utama yang paling baik diletakkan pada kalimat pertama paragraf.

b. Pembentukan Paragraf

Agar sebuah karangan mudah ditangkap pembaca dan jelas akan isi konteks yang diceritakannya, maka perlulah disusun suatu paragraf. Paragraf merupakan suatu pikiran atau perasaan yang tersusun teratur berupa kalimat-kalimat dan berfungsi sebagai bagian dari suatu satuan yang lebih besar, (Ahmadi dalam Masnur, 2009: 125). Paragraf bisa terseusun dari beberapa buah kalimat yang saling berhubungan sehingga merupakan satu kesatuan yang utuh untuk menyampaikan suatu maksud.

Sehubungan dengan hal ini W.J.S.Poerwadarminta dalam Masnur (2009: 126) mengemukakan sebagai berikut.

"Sekalian kalimat dalam paragraf bahumembahu, bekerjasama untuk menerangkan, melukiskan, atau mengulas suatu hal yang menjadi pokok pembicaraan dalam paragraf itu. Jadi, kalimat-kalimat dalam paragraf itu 
semuanya berpusat pada suatu pokok pembicaraan atau suatu tema."

Dengan demikian, untuk membuat suatu paragraf yang baik, kalimat-kalimat yang disusun hendaknya bertalian arti sehingga arti atau maksud tersebut menjadi jelas. Dalam hal ini anak didik dilatih menyusun paragraf secara teratur dalam bahasa tertulis. Kalimat yang bertalian arti, yaitu dalam satu paragraf kalimat-kalimatnya menerangkan, bahu-membahu, bekerja sama untuk menerangkan sesuatuatau pokok pembicaraan.

c. Penulisan Kalimat

Kalimat dalam karangan harus jelas dan mudah dipahami, karena kalimat tertulis dalam beberapa hal tidak sama dengan kalimat tutur. Kalimat yang jelas dan terang dalam bahasa percakapan (tutur), tidak selamanya jelas dan terang, juga apabila dituliskan, sebab intonasi dalam bahasa tutur sulit untuk diterjemahkandalam bahasa tulis.

Dalam setiap kalimat pada suatu karangan pada dasarnya kalimat itu disusu oleh unsur-unsur yang membentuknya. Unsur-unsur itulah yang membangun dan membentuk suatu kalimat. Unsur-unsur kalimat itu tidak lain adalah kata-kata. Kata-kata itulah yang membentuk kalimat. Bagian bagian kaliamt sering disebut konstituen Masnur (2009: 127).

\section{d. Penggunaan Tanda Baca}

Karangan selalu berupa bahasa yang tertulis. Dalam beberapa hal bahasa tertulis tidak sama dengan bahasa lisan. Banyak alat-alat bahasa seperti lagu, jeda, tinggi rendah suara, tekanan suara, sukar digambarkan dalam bahasa tulis. Untuk melengkapi kekurangan itu maka dibuatlah tanda baca. Menurut Poerwadarminta tanda baca dapat membantu menjelaskan maksud atau makna kalimat. Dengan tanda baca penulis dapat menyampaikan maksudnya dengan lebih jelas. Sedanga pembaca pun dapat pula menangkap maksud kalimat dengan lebih mudah. Oleh karena itu, makna tanda baca tidak boleh di abaikan dalam tulis-menulis Poerwadarminta dalam Masnur (2009: 127).

Pada dasarnya belajar adalah proses perubahan di dalam diri manusia dari apa yang tidak di ketahui berubah menjadi tahu. Belajar adalah suatu bentuk pertumbuhan dan perubahan didalam diri seseorang yang dinyatakan dalam cara- cara bertingkah laku yang baru berkat pengalaman dan latihan ( Aqib, $2010: 42$ )

Menurut Dimyanti dan Mudjiono (2009 : 7) berpendapat bahwa belajar adalah merupakan tindakan dan perilaku siswa yang kompleks. Sebagai tindakan maka belajar hanya di alami oleh siswa sendiri. Proses belajar terjadi berkat siswa memperoleh sesuatu yang ada di sekitar.

Berdasarkan pendapat di atas penulis menyimpulkan pengertian belajar adalah suatu proses yang terjadi di dalam diri manusia dari untuk belajar dari apa yang tidak di ketahui agar menjadi tahu serta pengetahuan tersebut dapat di realisasikan dalam kehidupan bermasyarakat.

Untuk mendapatkan suatu prestasi tidaklah semudah yang di bayangkan, karena memerlukan perjuangan dan pengorbanan dengan berbgai tantangan yang harus di hadapi. Menurut djamarah (2005 : 23-24) bahwa prestasi belajar itu adalah penilaian 
pendidikan tentang kemajuan siswa dalam segala hal yang di pelajari di sekolah yang menyangkut pengetahuan atau kecakapan yang dinyatakan sesudah hasil penilaian.

Prestasi Belajar Bahasa Indonesia Pembelajaran bahasa Indonesia memiliki peranan yang sangat penting bukan hanya untuk membina keterampilan komunikasi melaikan juga untuk kepentingan penguasaan ilmu pengetahuan. Melalui bahasalah manusia belajar berbagai pengetahuan yang ada di dunia. Mengingat fungsi penting pembelajaran bahasa, sudah selayaknya pembelajaran bahasa di sekolah di laksanakan dengan sebaikbaiknya. Pembelajaran bahasa haruslah diorientasikan pada pembentukan kemampuan berbahasa dan pembentukan kemampuan ilmu yang lain.
Dalam dunia pendidikan, menilai merupakan salah satu kegiatan yang tidak dapat ditinggalkan. Menilai merupakan salah satu proses belajar dan mengajar. Di Indonesia, kegiatan menilai prestasi belajar bidang akademik di sekolah-sekolah dicatat dalam sebuah buku laporan yang disebut rapor. Dalam rapor dapat diketahui sejauh mana prestasi belajar seorang siswa, apakah siswa tersebut berhasil atau gagal dalam suatu mata pelajaran.

Hasil penelitian prestasi belajar siswa pada mata pelajaran bahasa indonesia pada kelas VIII di MTs Tarbiyah Kabupaten Rejang Lebong pada aspek kebahasaan yang mencakup aspek morfologis dan sintaksis datanya di peroleh melalui lembar kerja siswa seperti dapat dilihat dalam tabel berikut:

Tabel Penilaian Hasil Belajar Bahasa Indonesia Siswa

\begin{tabular}{|c|l|c|}
\hline No & \multicolumn{1}{|c|}{ Nama Siswa } & Skor \\
\hline 1 & Achmad Vivin. P & 80 \\
\hline 2 & Akbar Hidayatullah & 80 \\
\hline 3 & Alpin Kristiawan & 72 \\
\hline 4 & Annisah Puspita sari & 76 \\
\hline 5 & Apriyanto irawan & 68 \\
\hline 6 & Arman Zurianto & 64 \\
\hline 7 & Cici Meisita Sari & 84 \\
\hline 8 & Debi Asmek & 84 \\
\hline 9 & Dhea Anzeliningsyi & 76 \\
\hline 10 & Diah Permata A. N & 76 \\
\hline 11 & Dina Merlianti & 76 \\
\hline 12 & Eko Rahmad & 76 \\
\hline 13 & Erika Ermiati & 76 \\
\hline 14 & Inayah Trinoviani & 72 \\
\hline 15 & Indah Hairu Santi & 76 \\
\hline 16 & Indah Putri Rahayu & 76 \\
\hline 17 & Kevin Hadiwilyah & 76 \\
\hline 18 & Mefi Kirna & 76 \\
\hline 19 & M. Alwan Rafi & 76 \\
\hline 20 & M Ikhsan & 76 \\
\hline 21 & M. Iqbal Agusman & 76 \\
\hline 22 & M. Yusuf & 76 \\
\hline
\end{tabular}




\begin{tabular}{|c|l|c|}
\hline No & \multicolumn{1}{|c|}{ Nama Siswa } & Skor \\
\hline 23 & Mutya Qarunia Sari & 76 \\
\hline 24 & Refidatul Hazanah & 76 \\
\hline 25 & Regi Saputra Utama & 76 \\
\hline 26 & Reza Saputra Sihotang & 76 \\
\hline 27 & Ruth Novaulina. S & 76 \\
\hline 28 & Saur Gabe Samosir & 76 \\
\hline 29 & Sefi Darmawan & 76 \\
\hline 30 & Silva Amelia & 76 \\
\hline 31 & Sinta Dwi Cahya & 76 \\
\hline 32 & Sri Rahayu Wahyuni & 80 \\
\hline 33 & Susan chintya Zulfani & 80 \\
\hline 34 & Teddy Ahmad Wirawan & 80 \\
\hline 35 & Tia Rahma Puspa R & 76 \\
\hline 36 & Yenni Ariani & 80 \\
\hline 37 & Yudi Darmawan & 76 \\
\hline 38 & Zafran Assyafiq Andre & 76 \\
\hline 39 & Zega Janotha & 80 \\
\hline 40 & Zulni Satria & 80 \\
\hline & $\quad$ Jumlah & 3060 \\
\hline & Nilai rata- rata & 76,5 \\
\hline
\end{tabular}

Berdasarkan data penelitian prestasi belajar bahasa Indonesia siswa kelas VIII di MTs Tarbiyah Islamiyah di Kabupaten Rejang Lebong di atas pada aspek keterampilan berbahasa yang meliputi aspek morfologi dan sintaksis, dari 40 Siswa 2 orang siswa mendapatkan nilai 84,8 orang siswa mendapatkan nilai 80,25 orang siswa mendapatkn nilai 76,2 orang siswa mendapatkan nilai 72,1 orang mendapatkan nilai 68,3 orang mendapatkan nilai 64, dengan jumlah keseluruhan 3060, serta berada pada nilai rata- rata kelas 76,5

Berdasarkan hasil penelitian tentang 'Prestasi Belajar Bahasa Indonesias Siswa kelas VIII di MTs Tarbiyah Islamiyah Kabupaten Rejang Lebong"pada aspek keterampilan berbahasa yang meliputi aspek morfologi dan sintaksis, dari 40 Siswa 2 orang siswa mendapatkan nilai 84,8 orang siswa mendapatkan nilai 80, 25 orang siswa mendapatkn nilai 76, 2 orang siswa mendapatkan nilai 72, 1 orang mendapatkan nilai 68,3 orang mendapatkan nilai 64 , dengan jumlah keseluruhan 3060, serta berada pada nilai rata- rata kelas 76,5

Berdasarkan hasil uji coba terdapat 3 soal yang tidak valid jadi soal yang hanya bisa di ujikan hanya berjumlah 22 soal

\section{Simpulan}

Berdasarkan hasil penelitian dan pembahasan, maka dapat disimpulkan:

Prestasi Belajar Bahasa Indonesia siswa kelas VIII di MTs Tarbiyah Islamiyah Kabupaten Rejang Lebong" berada pada rentang 70-79, dengan 
tingkat rata- rata sebesar 76,5 dan termasuk dalam kategori baik.

\section{Saran}

Berdasarkan hasil penelitian yang diperoleh maka penulis memberikan saran sebagai berikut :

1. Siswa hendaknya lebih di motivasi untuk lebih berperan aktif dalam proses belajar mengajar.

2. Bagi guru tidak hanya menguasai menguasai aspek morfologis dan sintaksis saja tetapi ada unsur lainnya juga.

\section{Daftar Pustaka}

Abidin, Yunus. 2012. Pembelajaran Bahasa Berbasis Pendidikan Karakter. Bandung : Refika Aditama.

Aliadi, Jemi. 2011. Kritik Struktur Tema dalam Novel Si Anak Kampoeng Karya Demian Dematra. Bengkulu : Dalam Skripsi Universitas Muhammadiyah Bengkulu. Tidak di Publikasikan.

Aqib, Zainal. 2010. Profesionalisme Guru dalam pembelajaran. Surabaya: Insan

Arikunto, Suharsimi.2006. Prosedur penelitian suatu pendekatan praktik.Jakarta : PT Rineka Cipta.
Dimyanti dan Mudjiono.2009. Belajar dan Pembelajaran.Jakarta : Rineka Cipta

Djamarah.2005. Guru dan Anak Didik dalam Interaksi Deduktif. Jakarta : PT Rineka Cipta

Kusmiarti, Reni. 2010. Bahan Ajar Morfologi. Bengkulu: Universitas Muhammadiyah Bengkulu

Ratna, Nyoman Kutha. 2009. Teori Metode dan Teknik Penelitian Sastra. Yogyakarta : Pustaka pelajar

Saifuddin, Azwar.1998. Tes Prestasi Fungsi dan Pengembangan Pengukuran Prestasi Belajar. Yogyakarta : Pustaka Belajar Offset

Susandi.2009. Morfologi. Dalam https://susandi.wordpress.com/sep utar-bahasa/morfologi-2/ di unggah pada tanggal 30 oktober 2015 